$\S=2$ 原

\title{
Evaluation of hydraulic conductivity of lateritic soils using integrated approach: southwestern Nigeria case study
}

\author{
Fajobi A.B. ${ }^{1}$, Falade F. A. ${ }^{2}$, Adepelumi A.A ${ }^{3 *}$, Akindulureni J. O. ${ }^{3}$ \\ ${ }^{1}$ Department of Civil Engineering, Obafemi Awolowo University, Ile-Ife, Nigeria \\ ${ }^{2}$ Department of Civil Engineering, University of Lagos, Lagos, Nigeria \\ ${ }^{3}$ Department of Geology, Obafemi Awolowo University, Ile-Ife, Nigeria \\ *Corresponding author E-mail: adepelumi@gmail.com
}

\begin{abstract}
The source of groundwater seepage problem being experienced by some engineering buildings in a part of southwestern Nigeria was investigated by carrying out comparative study of the hydraulic conductivity $(\mathrm{K})$ of the soil types underlying the area using integrated approaches involving geotechnical and geophysical methods.

Soil samples were collected from six different towns on which standard geotechnical tests including natural moisture content, grain size distribution, linear shrinkage, specific gravity, liquid and plastic limits, compaction, triaxial and $\mathrm{K}$ test were carried out. Also, geophysical data were acquired at seventy-two locations using Schlumberger array with a current electrode spacing of $40 \mathrm{~m}$. The resistivity data obtained were subsequently inverted to obtain the subsurface 2D hydraulic conductivity section.

The results obtained imply that the soil types investigated is semi-pervious with $\mathrm{K}$ values ranging from $1.06 \times 10^{-5}$ to $5.71 \mathrm{x} 10^{-5} \mathrm{~cm} / \mathrm{s}$. These values suggest moderate groundwater flow which might account for the seepage that was observed. Four lithologies (lateritic topsoil, clayey-sand, sandy-clay and fractured/weathered bedrock) were delineated. The geotechnical analysis result suggests the soil investigated could be classified as poorly graded sandy-clay and/or silty-clay. This soil exhibit plasticity index ranging from 12.72 to $19.75 \%$, with specific gravity ranging from 2.47 to 2.73 ; the maximum dry density (MDD) varies from $1699.5 \mathrm{~kg} / \mathrm{cm}^{3}$ to $1915 \mathrm{~kg} / \mathrm{cm}^{3}$ and the optimum moisture content (OMC) ranges from $12.05 \%$ to $16.32 \%$. The result of the t-test results performed implied that at $95 \% \mathrm{t}-$ confidence level, there is a good correlation between the results obtained from both approaches employed.
\end{abstract}

Keywords: Geotechnical Tests; Groundwater Seepage; Hydraulic Conductivity; Resistivity; Soil.

\section{Introduction}

Lateritic clay has been found to be one of the most abundant soils in the tropical part of the world. Its availability has enhanced its usage as materials for the construction of roads, airfields, earth dams, and foundation of structures. Engineers are primarily interested in a soil's mechanical properties such as strength, stiffness and permeability.

The hydraulic conductivity $(\mathrm{K})$ of soils is a key parameter that is required for analysis and design of numerous civil engineering works such as seepage, groundwater development, consolidation, drainage, contaminant studies. The hydraulic conductivity of saturated soils varies significantly from approximately $10^{-13} \mathrm{~m} / \mathrm{s}$ for high plasticity clays to $1 \mathrm{~m} / \mathrm{s}$ for clean, uniformly graded, coarse gravels. DeGroot et al. (2012) showed that this large range in values has resulted in the development of numerous field methods that cater to the soil type being tested and the anticipated hydraulic conductivity.

In civil engineering practice, geotechnical parameters such as permeability of rocks and soils are required for subsurface characterization. It is commonly determined from geotechnical approach such as pump tests, grain size analysis, which involves drilling or digging in order to obtain samples; which over a large area are cumbersome, time-consuming and expensive.
Several approaches have been used to determine the hydraulic conductivity of both the unsaturated and saturated soils found in the tropical and temperate regions of the world. For example, Yu et al. (2013) used an integrated approach to investigate the hydraulic conductivity of clay soil. Their result showed good degree of correlation among methods. Odong (2013) and Justine (2007) showed that empirical technique is fast and efficient for determining hydraulic parameters of soils using the grain size analysis method. They suggest that unless the appropriate robust empirical such as the Kozeny-Carman formula method is employed, the hydraulic conductivity values estimated may be either underestimated or overestimated. Sobotkova et al. (2011) used inverse modeling and column experiment to derive the hydraulic conductivity of the oxisol soil found in the tropical area of Hawaii, USA. They obtained results that are consistent with the tropical soils. Edoga (2010) conducted saturated hydraulic conductivity using the constant head permeameter method at four sites with samples taken at different depths $(15,30,45,60 \mathrm{~cm})$ at Samaru, Zaria. He used the redefined Kozney Carman model and Yannopoulos equations to predict hydraulic conductivity and the results obtained from the laboratory technique were compared favourably with the Kozney-Carman and Yannopoulos prediction models. However, Shevnin et al. (2006) reported on the estimation of hydraulic conductivity in soil using the resistivity data (geophysical method). They confirmed the influence of the clay contents on the hy- 
draulic conductivities determined. But Xu and Dong (2004) proposed the fractal technique for predicting the hydraulic conductivity of unsaturated porous media for geophysical, geotechnical and agricultural applications. Simunek and Genuchten (1996) adopted an inverse modeling procedure to estimate the soil hydraulic characteristics of a two-layered soil system - soil surface crust and subsoil-from data obtained during a tension-disc infiltration experiment. Similarly, Kodesová et al. (1998) and Kodesová et al. (1999) presented results of field testing of inverse modeling in two types of soil using the cone penetrometer method.

However, the geophysical approach such as electrical resistivity sounding, which is non-invasive, requires no perforation, and can produce information faster than drilling. There have been several attempts in the past to obtain quantitative information on relationship between hydraulic conductivity and resistivity. Katsube and Hume (1987), Nishimakiet al. (1999), and Suzuki (2002) have all shown that rock permeability is proportional to rock resistivity.
On the other hand, Matsui et al. (1977) showed that resistivity increases with increasing hydraulic conductivity at low to moderate values of resistivity, while resistivity increases with decreasing hydraulic conductivity where the range of resistivity is moderate to high, in granitic rocks. Sudoet al. (2004) showed that the relationship between resistivity and hydraulic conductivity of granitic rocks can be interpreted with crack models.

The thrust of this research work is the investigation of the hydraulic properties of the subsoil existing in six major towns that are located in parts of Ile-Ife, Akure, Ibadan, Ondo, Ogbomoso and Ilesha, southwestern Nigeria (Fig. 1) using combined geotechnical and geophysical approaches. For this study, geophysical method was considered as an alternative cost effective method for potential groundwater seepage mapping in an area where groundwater seepage is threatening the foundation of existing engineering buildings.

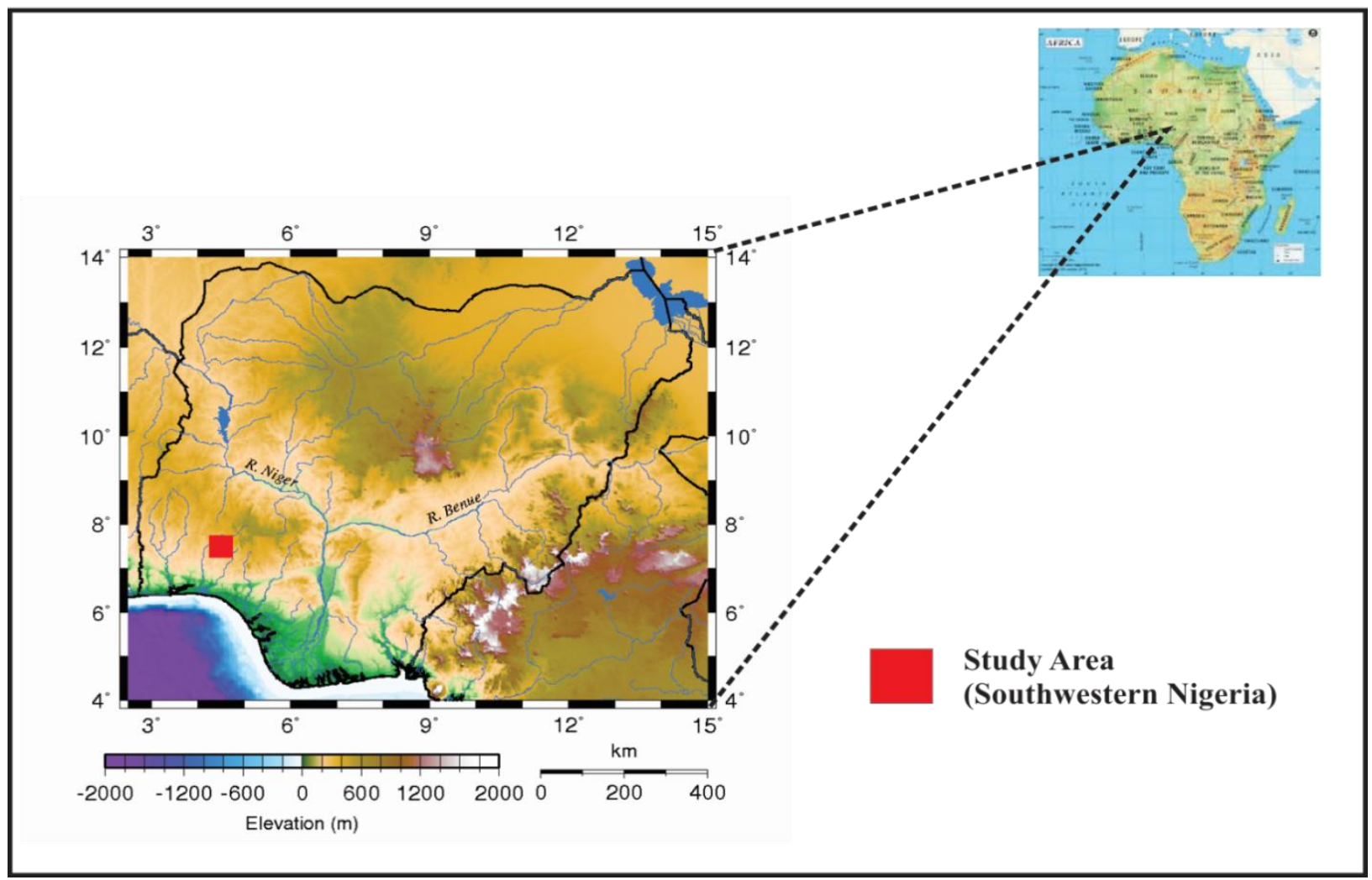

Fig. 1: Location Map of Study Area in South western Nigeria

\section{Geology of the area under study}

The study area is underlain by the Precambrian Basement complex rocks of Southwestern Nigeria. The local geologic units identified in the study area are the Migmatitic-Gneisses. They are composed of three main components namely: Early Gneiss, MaficUltramafic Bands and Granitic or Felsic Component. Rahaman (1988) classified the major lithological rock units of the complex into two major groups: gneisses and schists, with minor occurrence of intrusive mafic/ ultramafic rocks that probably represent remnants of an oceanic assemblage. Due to intense tropical weathering, the bedrock weathered into thick regolith overburden materials that vary from lateritic clay, clayey sand, to sand (Adepelumi et al., 2001). There are also minor Pegmatite vein and quartz vein intrusions. Field relationship shows that the granite gneiss which forms the large residual hills in addition to a few low-level outcrops is intrusive into the grey gneiss. This interpretation is based on the occurrence of grey gneiss in the granite gneiss. All the rocks are either weakly deformed and as a result show microfolds and microfaults.

\section{Methodology}

Thirty-six test pits, each $3 \mathrm{~m}$ deep were dug at six selected towns (Ile-Ife, Akure, Ibadan, Ondo, Ogbomoso and Ilesha) in southwestern Nigeria. The sampling locations is at the geographic coordinates (Latitude and Longitude) $7^{\circ} 30^{\prime} 51^{\prime \prime N} / 4^{\circ} 29^{\prime} 35^{\prime \prime} \mathrm{E}$, $7^{\circ} 24^{\prime} 15^{\prime \prime} \mathrm{N} / 5^{\circ} 17^{\prime} 20^{\prime \prime} \mathrm{E}, \quad 8^{\circ} 12^{\prime} 30^{\prime \prime N} / 3^{\circ} 11^{\prime} 28^{\prime \prime} \mathrm{E}$ $7^{\circ} 10^{\prime} 54^{\prime \prime N} / 4^{\circ} 58^{\prime} 18^{\prime \prime E}, 8^{\circ} 08^{\prime} 19^{\prime \prime N} / 4^{\circ} 15^{\prime} 13^{\prime \prime E a n d ~}$

$7^{\circ} 37^{\prime} 43^{\prime \prime N} / 4^{\circ} 44^{\prime} 30^{\prime \prime E}$. At the sites, soil samples were collected at regular intervals of $0.6 \mathrm{~m}, 1.2 \mathrm{~m}, 1.8 \mathrm{~m}, 2.4 \mathrm{~m}$ and $3.0 \mathrm{~m}$ vertically downward in the pits. The soil samples were subjected to geotechnical laboratory tests in accordance with BS1377 (1990) standard to obtain their characteristics geotechnical and soil profile properties. The laboratory tests performed on air dried soil samples are: grain size distribution, specific gravity, liquid and plastic limits, compaction, triaxial test and hydraulic conductivity of the lateritic soil samples.

For the electrical resistivity method, the Schlumberger configuration was used throughout the survey with the half-current electrode spacing $(\mathrm{AB} / 2)$ used varying from $1 \mathrm{~m}$ to $40 \mathrm{~m}$. A total of seventy-two (72) VES points along eighteen(18) traverses were 
occupied.The apparent resistivity data obtained at each of the 72 VES stations were plotted against the half-current electrode spacing $(\mathrm{AB} / 2)$ using Pirttijärvi (2013 version) electrical sounding software. The model description generated the resistivity value of soil layers, the layer thickness and the depth at each VES stations considered which helped in deciphering the soil layers at the survey site.

In order to evaluate the relationship between resistivity and hydraulic conductivity in the study area and obtain insight about the hydrological conditions vis-à-vis groundwater flow regime in the area, the apparent resistivity data acquired were inverted to create a model of $2 \mathrm{D}$ subsurface resistivity sections that were transformed to a 2D permeability section using DIPRO (2012 version) inversion program. The empirical formula employed was established by Ogata et al. (1992) and Sudo et al. (2004) for estimating the hydraulic conductivity $(\mathrm{K})$ of clayey sand/clay and lateritic clay given as;

$K=3.545 \times 10^{-11} \times \rho^{3.9072}$

Where $\mathrm{K}=$ hydraulic conductivity in $\mathrm{cm} / \mathrm{sec}$, and $\rho=$ apparent resistivity in Ohm-m.

For the purpose of establishing the relationship between the resistivity and the hydraulic conductivity (K) existing for the area of study; the $\mathrm{K}$ values obtained using the $\mathrm{K}$ formula above were plotted against the resistivity values retrieved from the inverted resistivity along traverses 1,2 and 3 respectively.

\section{Results and discussions}

\subsection{Geoelectrical section along the traverses}

For the six towns investigated, the subsurface geology delineated has similar lithology (soil types) with minor variation of thicknesses and resistivity values. The subsurface Geoelectrical sections along three traverses (Traverses 1,2 and 3) are presented in Fig. 2.These sections revealed that there are four distinct geological layers at the survey sites; lateritic top soil, clayey-sand, sandyclay layer and weathered bedrock and bedrock

The top soil has resistivity values ranging from 41 Ohm-m to 909 Ohm-m with a thickness layer range of $1.30 \mathrm{~m}-2.83 \mathrm{~m}$. This layer consists of lateritic/clayey top soil. The clayey-sand has resistivity values ranging from 94.7 to $424.5 \mathrm{Ohm}-\mathrm{m}$ with a thickness of $1.50 \mathrm{~m}-3.89 \mathrm{~m}$. The third layer resistivity value varies from 187.1 $3736.3 \mathrm{Ohm}-\mathrm{m}$ and its thickness is between $1.48 \mathrm{~m}-7.75 \mathrm{~m}$, this is the sandy-clay layer. The fourth layer has resistivity value as low as 50.7 Ohm-m and as high as $5645.10 h m-m$, this represents the fractured bedrock and bedrock respectively. Between VES 4 and 6 , a depression zone which possibly contains conductive liquid was observed. Forward modelling results generated by Adepelumi et al. (2006) indicates that such depression is likely to be fractured bedrock in which water may have accumulated.

\subsection{Hydraulic conductivity and resistivity of soil}

Figure 3shows the hydraulic conductivity sections obtained from the transformation of the resistivity data obtained along the traverses. Four distinct hydrologic regimes labelled A, B, C and D are recognisable in the three sections. The regime corresponds to the subsurface lithology existing in the area under study. The weathered/fractured layer constitutes the main aquifer which serves as a conduit for groundwater seepage in the area.

Generally, from the inverted resistivity result for traverse 1 (Fig $3 \mathrm{a}$ ), the $\mathrm{K}$ values retrieved vary from $3.3 \times 10^{-9}$ to $2.2 \mathrm{~cm} / \mathrm{s}$ with a root mean square (rms) error of $7.25 \%$. The topsoil marked $\mathrm{A}$ is the most permeable with $2.2 \mathrm{~cm} / \mathrm{s}$. It is apparent that the bedrock depression zone has high $\mathrm{K}$ which possibly results in high ground water flow. For traverse 2 (Fig. 3b), The $\mathrm{K}$ values varies from 5.4 $\mathrm{x} 10^{-10}$ to $5.6 \mathrm{~cm} / \mathrm{s}$ with arms error of $5.19 \%$. The $\mathrm{K}$ value around the basement depression varies from 2.8 to $5.6 \mathrm{~cm} / \mathrm{s}$. These values suggest that the depression area is a good aquifer; hence it might account for the continuous flow of ground water observed in the region. However, for traverse 3 (Fig. $3 \mathrm{c}$ ), the $\mathrm{K}$ values $\left(1.2 \times 10^{-7}\right.$ to $1.5 \times 10^{-3} \mathrm{~cm} / \mathrm{s}$ ) obtained along this traverse is however low compared to traverses 1 and 2 . The rms error associated with this inverted result for traverse 3 is $2.58 \%$. Since the $\mathrm{K}$ value obtainedfrom the inversion for traverses 1 and 2 is higher than traverse 3 , this possibly suggest that the soil beneath traverse 3 is more saturated.

The relationship existing between resistivity $(\rho)$ and hydraulic conductivity along traverses 1,2 and 3 respectively is presented in Fig. 4. It is obvious that a distinct linear relationship exist between the derived $K$ and $\rho$ values at all the locations. The geologic implication of this is that the soil types are strongly influenced by the $\mathrm{K}$ values.This suggests that a decrease in hydraulic conductivity would lead to increase in resistivity and vice versa.

\subsection{Statistical t-test for comparison of hydraulic con- ductivities}

When hydraulic conductivities $(\mathrm{K})$ measurements are made using different techniques, it is important to determine whether the $\mathrm{K}$ values estimated are different between sample locations. To investigate this effect, statistical tests were used. The t-test compares the actual difference between two means of the $\mathrm{K}$ values in relation to the variation in the data expressed as the standard deviation of the difference between the means of the $\mathrm{K}$.

The $\mathrm{K}$ values are considered significantly different if the $95 \%$ confidence interval for their averages overlap ( $t$ test with $\mathrm{a}=0.05$ ). For this purpose, the statistical t-test was conducted on the $\mathrm{K}$ values obtained from both the geophysical and geotechnical approaches. Table 1 shows the average $\mathrm{K}$ values obtained using the two techniques. From Table 1, it is evident that $\mathrm{K}$ values ranges from $1.18 \times 10^{-5} \mathrm{~cm} / \mathrm{sec}$ to $6.40 \times 10^{-5} \mathrm{~cm} / \mathrm{sec}$.

The result of the $t$ test $(a=0.05)$, as summarized in Table 2, indicated that there is a slight difference in the geometric mean of the $\mathrm{K}$ values using the two techniques but the difference is not significant.This means that there is a $95 \%$ chance of the means not being significantly different. The implication of the t-test result is that we could still rely on the $\mathrm{K}$ values predicted using any of the two methods.Also, the correlation coefficients obtained between the two approaches is 0.9258 ; this signifies a strong positive linear correlation.

\begin{tabular}{|c|c|c|c|c|c|c|}
\hline \multirow{3}{*}{$\begin{array}{l}\text { Sampling } \\
\text { Locations in } \\
\text { Southwest- } \\
\text { ern Nigeria }\end{array}$} & \multicolumn{6}{|c|}{ Hydraulic Conductivities $(\mathrm{cm} / \mathrm{sec})$} \\
\hline & \multicolumn{3}{|c|}{ Geophysical Field Results } & \multicolumn{3}{|c|}{ Geotechnical Results } \\
\hline & $\begin{array}{l}\text { Sam- } \\
\text { ple 1 }\end{array}$ & $\begin{array}{l}\text { Sam- } \\
\text { ple } 2\end{array}$ & $\begin{array}{l}\text { Sam- } \\
\text { ple } 3\end{array}$ & $\begin{array}{l}\text { Sam- } \\
\text { ple 1 }\end{array}$ & $\begin{array}{l}\text { Sam- } \\
\text { ple } 2\end{array}$ & $\begin{array}{l}\text { Sam- } \\
\text { ple } 3\end{array}$ \\
\hline Ile-Ife & $\begin{array}{l}2.38 \mathrm{x} \\
10^{-5}\end{array}$ & $\begin{array}{l}2.56 \mathrm{x} \\
10^{-5}\end{array}$ & $\begin{array}{l}2.71 \mathrm{x} \\
10^{-5}\end{array}$ & $\begin{array}{l}1.40 \mathrm{x} \\
10^{-5}\end{array}$ & $\begin{array}{l}2.81 \mathrm{x} \\
10^{-5}\end{array}$ & $\begin{array}{l}3.25 x \\
10^{-5}\end{array}$ \\
\hline Akure & $\begin{array}{l}1.06 \mathrm{x} \\
10^{-5}\end{array}$ & $\begin{array}{l}2.11 \mathrm{x} \\
10^{-5}\end{array}$ & $\begin{array}{l}1.85 \mathrm{x} \\
10^{-5}\end{array}$ & $\begin{array}{l}1.18 \mathrm{x} \\
10^{-5}\end{array}$ & $\begin{array}{l}1.48 \mathrm{x} \\
10^{-5}\end{array}$ & $\begin{array}{l}2.05 \mathrm{x} \\
10^{-5}\end{array}$ \\
\hline Ibadan & $\begin{array}{l}2.37 \mathrm{x} \\
10^{-5}\end{array}$ & $\begin{array}{l}2.43 \mathrm{x} \\
10^{-4}\end{array}$ & $\begin{array}{l}2.26 x \\
10^{-5}\end{array}$ & $\begin{array}{l}2.28 \mathrm{x} \\
10^{-5}\end{array}$ & $\begin{array}{l}2.52 \times \\
10^{-5}\end{array}$ & $\begin{array}{l}2.91 \times \\
10^{-5}\end{array}$ \\
\hline Ondo & $\begin{array}{l}4.69 \mathrm{x} \\
10^{-5}\end{array}$ & $\begin{array}{l}3.74 x \\
10^{-5}\end{array}$ & $\begin{array}{l}4.15 \mathrm{x} \\
10^{-5}\end{array}$ & $\begin{array}{l}1.99 \mathrm{x} \\
10^{-5}\end{array}$ & $\begin{array}{l}5.85 \mathrm{x} \\
10^{-5}\end{array}$ & $\begin{array}{l}5.85 \times \\
10^{-5}\end{array}$ \\
\hline Ogbomoso & $\begin{array}{l}3.40 \mathrm{x} \\
10^{-5}\end{array}$ & $\begin{array}{l}4.29 \mathrm{x} \\
10^{-4}\end{array}$ & $\begin{array}{l}4.17 \mathrm{x} \\
10^{-4}\end{array}$ & $\begin{array}{l}1.20 \mathrm{x} \\
10^{-5}\end{array}$ & $\begin{array}{l}4.20 \mathrm{x} \\
10^{-5}\end{array}$ & $\begin{array}{l}5.71 \times \\
10^{-4}\end{array}$ \\
\hline Ilesha & $\begin{array}{l}2.20 \mathrm{x} \\
10^{-5}\end{array}$ & $\begin{array}{l}2.38 \mathrm{x} \\
10^{-5}\end{array}$ & $\begin{array}{l}2.53 \mathrm{x} \\
10^{-5}\end{array}$ & $\begin{array}{l}1.84 \mathrm{x} \\
10^{-5}\end{array}$ & $\begin{array}{l}2.84 \mathrm{x} \\
10^{-5}\end{array}$ & $\begin{array}{l}3.44 \times \\
10^{-5}\end{array}$ \\
\hline
\end{tabular}

Table 2: Statistical T-Test Result of the Two Approaches Used in this Study

\begin{tabular}{|c|c|c|c|}
\hline Data & Mean & Variance & $\mathrm{N}$ \\
\hline $\begin{array}{l}\text { K Values derived from Geophysical } \\
\text { approach }\end{array}$ & 0.0000829 & $\begin{array}{l}1.79562 \mathrm{E}- \\
8\end{array}$ & 18 \\
\hline $\begin{array}{l}\text { K Values derived from Geotechnical } \\
\text { approach }\end{array}$ & 0.0000579 & $\begin{array}{l}1.65901 \mathrm{E}- \\
8\end{array}$ & 18 \\
\hline t-test & -0.57193 & & \\
\hline $\mathrm{P}$ & 0.57113 & & \\
\hline Correlation coefficients ( $\mathrm{r}$ ) & 0.92580 & & \\
\hline
\end{tabular}



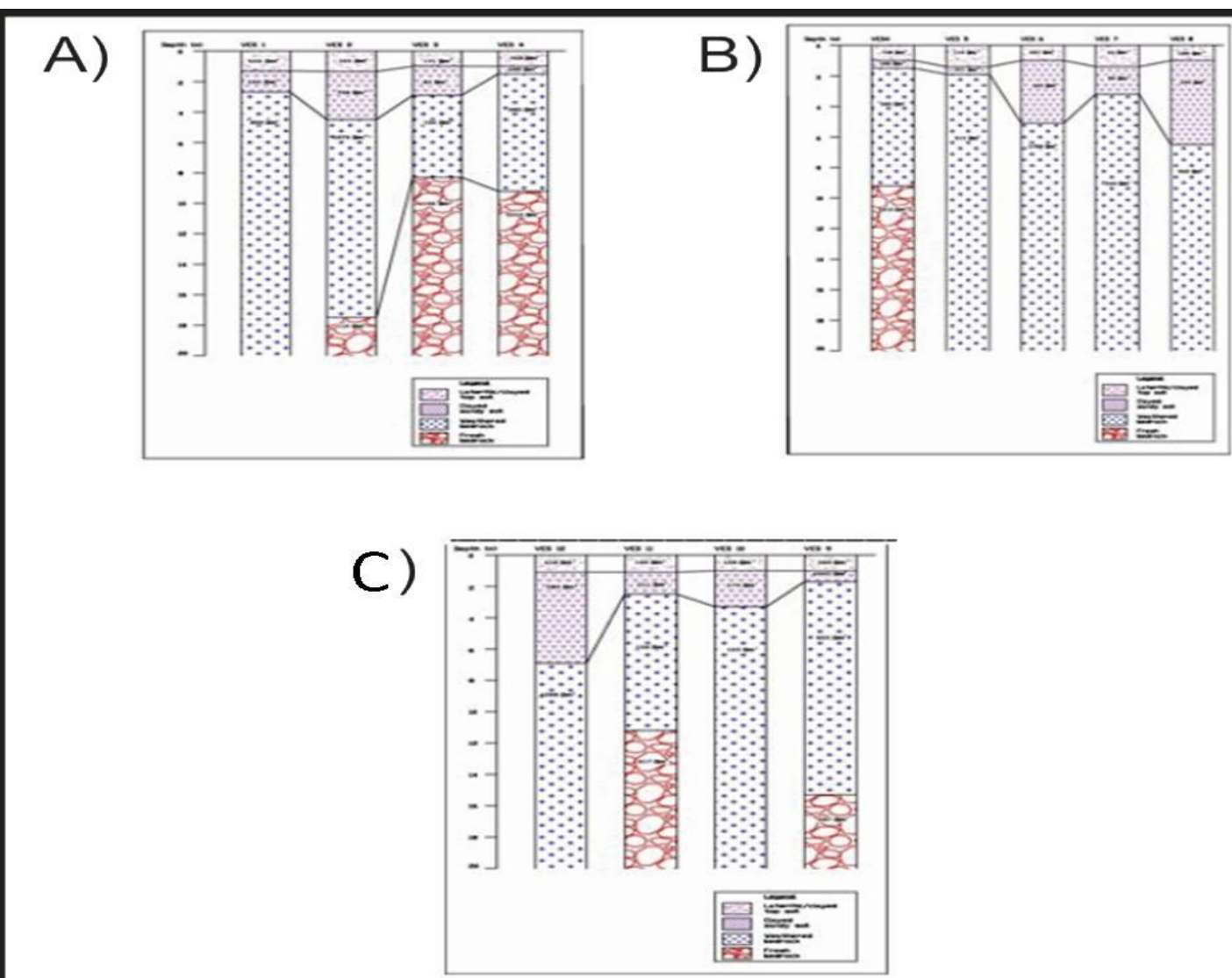

Fig. 2: Geoelectrical Section along Traverses 1, 2 And 3

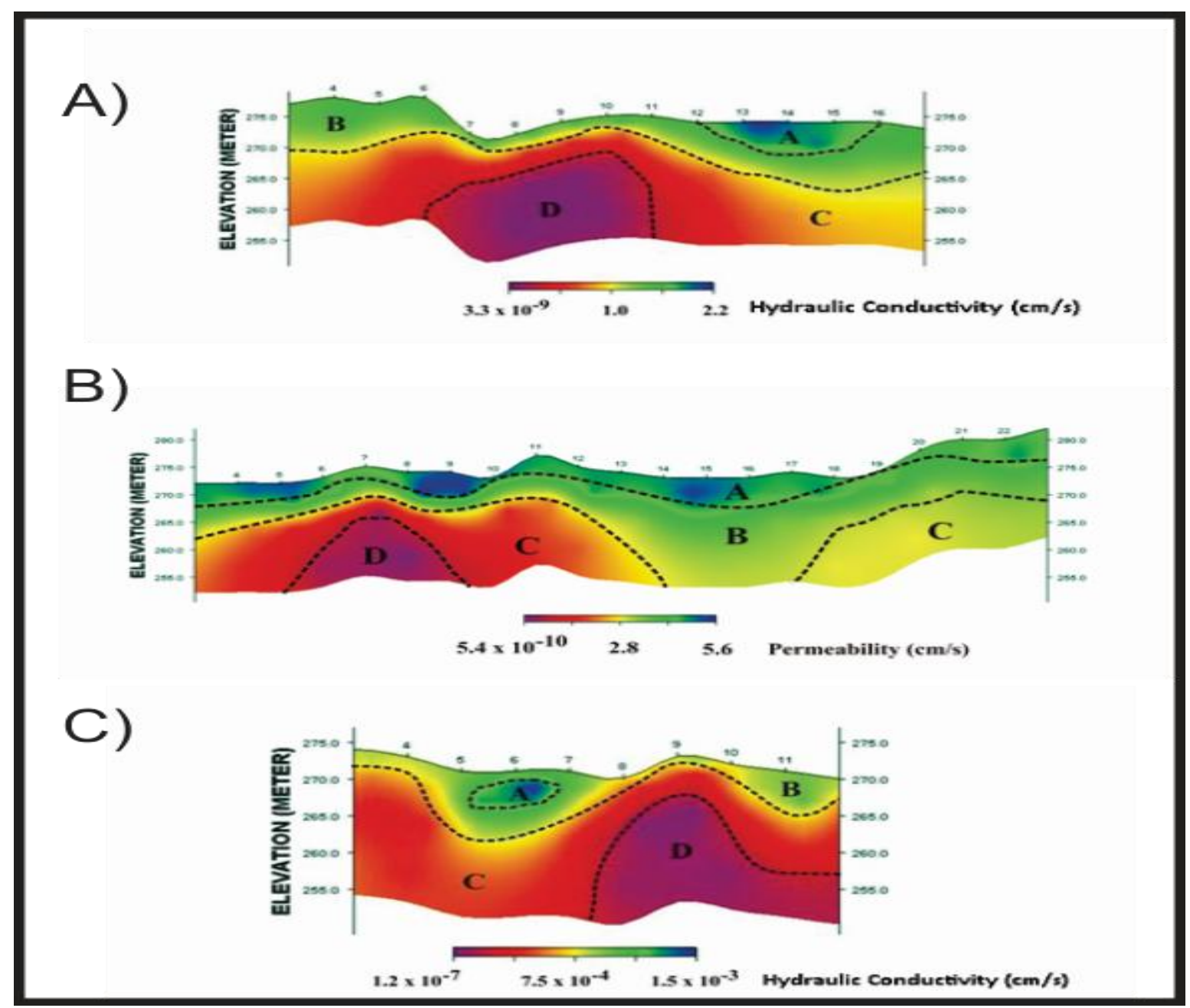

Fig. 3: Hydraulic Conductivity Sections Obtained from Resistivity Data 
A)

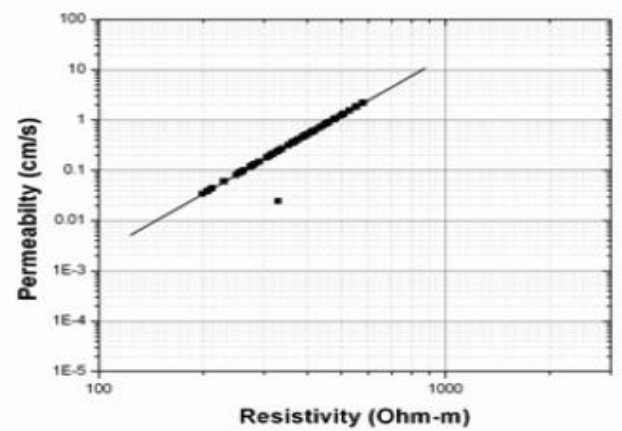

B)

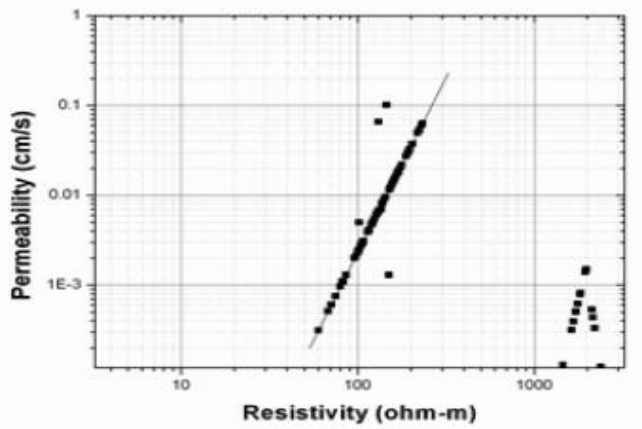

C)

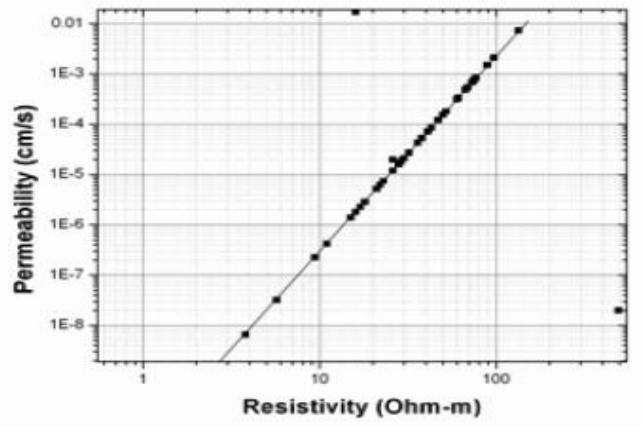

Fig. 4: Permeability Vs. Resistivity Plot

Table 3: Summary of the Geotechnical Test Result for Ile-Ife

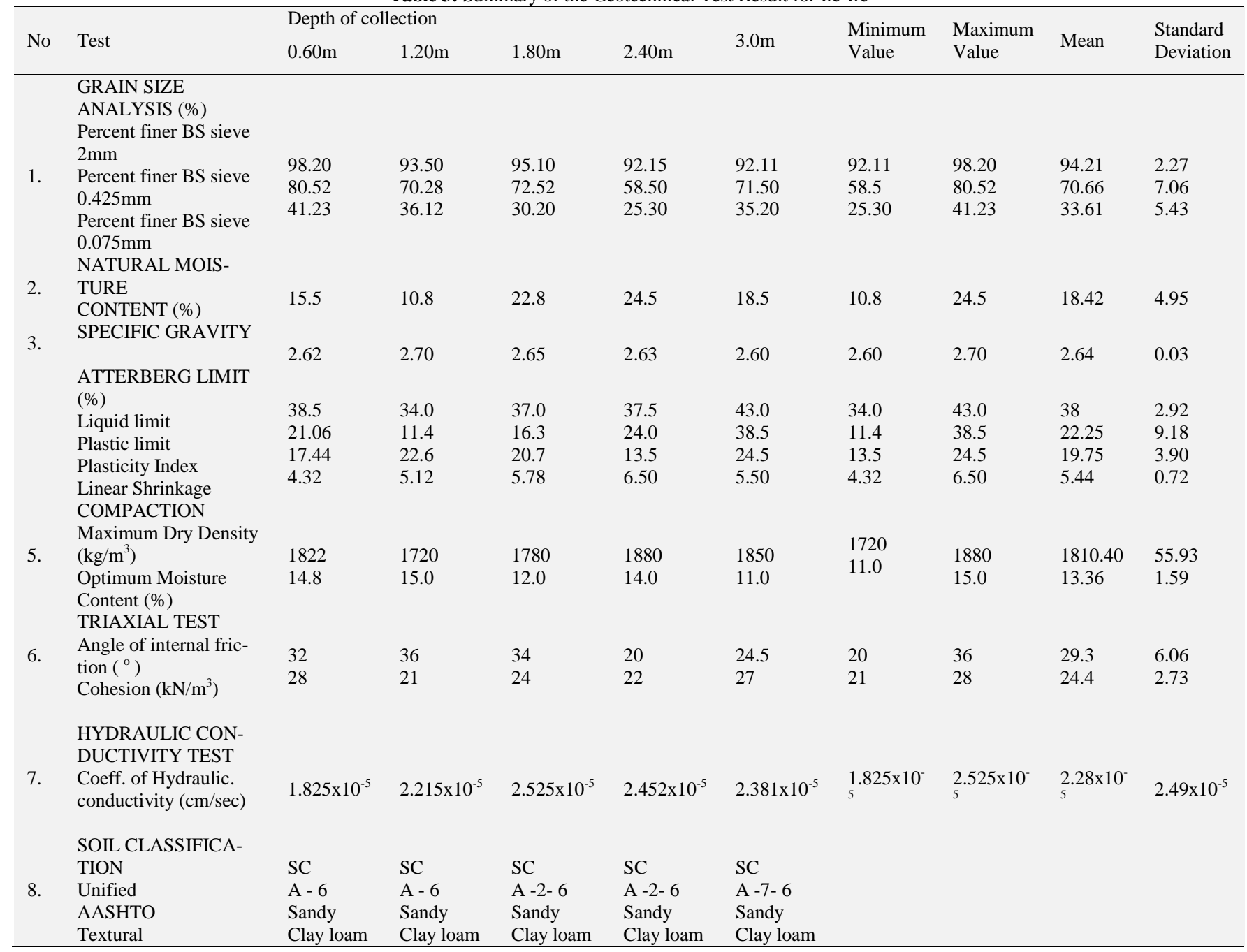




\subsection{Geotechnical test results}

Typical results of the geotechnical engineering test carried out on soil samples obtained in the investigated area are shown in Table 3. From the entire test carried out, it is observed that the natura moisture content of the soils in all the pits sampled was found to have mean range of $15.64 \%$ to $20.97 \%$. It is deduced that these values possibly depend on the climatic condition prevailing at the time of the sample collection. The specific gravity values obtained ranged from 2.47 to 2.73. Das (1990) showed that the specific gravity of clayey and silty soils vary from 2.6 to 2.9 . The values obtained from this study falls within this range. Further, the average percentage of soil passing through sieves $2 \mathrm{~mm}, 0.425 \mathrm{~mm}$ and $0.075 \mathrm{~mm}$ suggest that the grain sizes are between the sand and clayey soils range.

The average value of the liquid limit varies from $25.62 \%$ to $41.60 \%$ with mean value of $34.98 \%$, while plastic limit varies from ranges from $12.71 \%$ to $27.60 \%$ with mean value of $20.35 \%$.Also; the plasticity index varies from $12.72 \%$ to $19.75 \%$ with a mean value of $15.96 \%$ (See Table 3 ). The variation of plasticity index revealed that the soil samples are mainly inorganic clays of medium plasticity. The mean value of the linear shrinkage test varies from $4.77 \%$ to $8.90 \%$ with an average value of $6.33 \%$. The shrinkage property of a soil is dependent on the clay content and this could be attributed to the nature of the soil samples mineralogy.

\subsection{Soil classification}

The soils analysed in study area were classified according to Unified Soil Classification System (Unified), AASHTO Classification system and Textural Classification system as shown in Table 3. According to the Unified classification system of the soil samples, $13.3 \%$ of the soil samples fall into CL group, which indicated that they are inorganic clays of low to medium plasticity. The remaining $86.7 \%$ fall into SC group which indicated clayey soils; poorly graded sandy clayey mixture or inorganic clays of medium plasticity. Using AASHTO soil classification, it is obvious that $63.4 \%$ of the soil samples fall into A-2-6 group, 3.3\% into A-2-7, 13.3\% into A-6 and 20\% into A-7-6 groups respectively. A-2-6 and A-2-
7 groups have silty or clayey gravel and sand; while A-6 and A-76 have clayey soils in their own case. For Textural classification, $65 \%$ of the soil samples were classified as sandy clay soils while the remaining $34 \%$ are sandy clay loamy soils. It is pertinent to mention that these geotechnical test results agreed with the research findings of Olorunfemi and Okhue (1991) using geophysical approach.

\subsection{Compaction and triaxial test}

For the compaction test ,the maximum dry density (MDD) obtained varies from $1669.50 \mathrm{~kg} / \mathrm{m}^{3}$ to $1915.10 \mathrm{~kg} / \mathrm{m}^{3}$ with a mean value of $1834.75 \mathrm{~kg} / \mathrm{m}^{3}$.The corresponding optimum moisture content (OMC) of the soil samples in the study area ranges between $12.05 \%$ and $16.32 \%$ with a mean of $13.01 \%$. All these values falls within the range known for lateritic soils found in the tropical region.

For the triaxial test conducted on the soil samples, it is evident that the values of the cohesion (c) vary from the minimum value of $21.40 \mathrm{kN} / \mathrm{m}^{2}$ to maximum value of $31.80 \mathrm{kN} / \mathrm{m}^{2}$ while the angle of internal friction is between 24 to 27 degrees (See Table 3). This confirm the cohesive nature of the soil arising from the clayey particles coupled with interlocking friction which is due to the sandy part of the soil samples.

\subsection{Hydraulic conductivity test}

Hydraulic conductivity $(\mathrm{K})$ is a measure of the coefficient of soil permeability. Table 1 show the various values obtained for the pits dug in the six towns. Fig.5 shows the plot of the permeability against depth for all the pits sampled in this study. From the result, it is obviousthat the average $\mathrm{K}$ values vary from the minimum value of $1.18 \times 10^{-5} \mathrm{~cm} / \mathrm{sec}$ to $2.28 \times 10^{-5} \mathrm{~cm} / \mathrm{sec}$. Our findings point to the fact that the typical values of the coefficients of hydraulic conductivity $(\mathrm{K})$ of soils investigated in this study are within the range that could be defined as containing fine sand, silt and clay soils type as suggested by Das (1990).
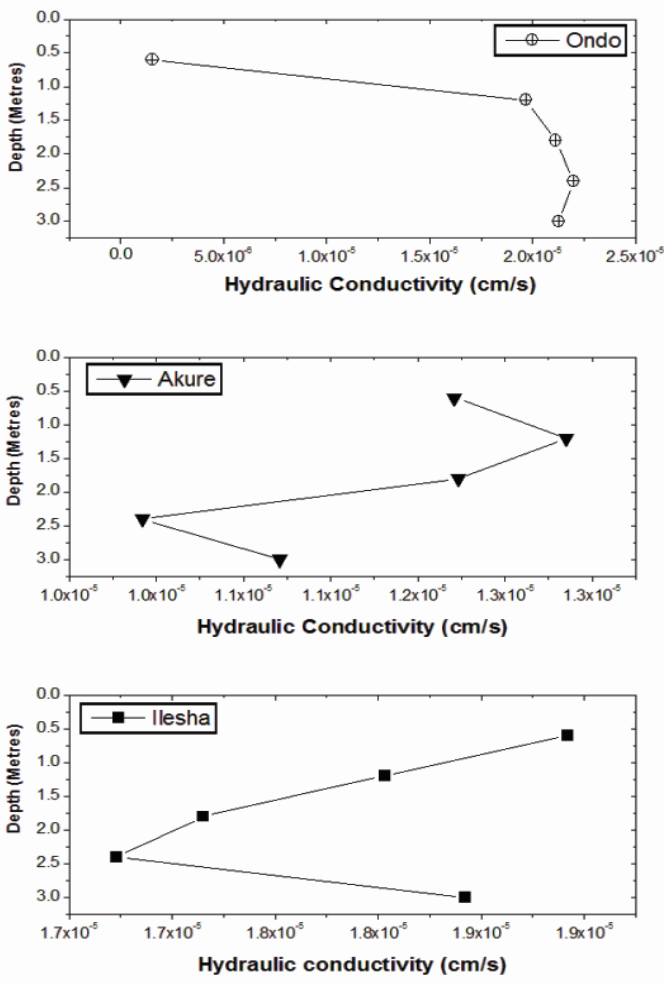

Fig. 5: Plot of Permeability against Depth 


\section{Conclusions}

Integrated approaches have been applied in determining the hydraulic conductivities of lateritic soils found in the tropical region of southwestern Nigeria. Some of the existing buildings in the area frequently encountered groundwater seepage problem. Based on Unified soil classification system, it is revealed that the soils in the study can be grouped as mainly SC group which shows poorly graded sandy clayey mixture or inorganic clays of medium plasticity. The hydraulic conductivity $(\mathrm{K})$ values obtained using geotechnical approach vary from $1.18 \times 10^{-5} \mathrm{~cm} / \mathrm{sec}$ to $5.71 \times 10$ ${ }^{4} \mathrm{~cm} / \mathrm{sec}$ which still shows that it lies within the range of soils having relative permeability that is semi-pervious; on the other hand, geophysical method delineated four distinct and ubiquitous soil layers: lateritic topsoil, clayey-sand, sandy-clay layer and fractured and/or weathered bedrock. The $\mathrm{K}$ values obtained using geophysical approach ranges from $1.06 \times 10^{-5} \mathrm{~cm} / \mathrm{sec}$ to $4.29 \times 10^{-}$ ${ }^{4} \mathrm{~cm} / \mathrm{sec}$.

Also, the hydraulic conductivity values obtained from the two methods suggest the existence of moderate groundwater flow in some section of the project area. This may likely be responsible for the groundwater seepage noted. Furthermore, the $\mathrm{t}$-test evaluation shows that at $95 \%$ confidence level, the results from both approaches are slightly different but strongly correlated. The reliability of using integrated approach for hydraulic parameter prediction and groundwater seepagemapping was confirmed from this study.

\section{References}

[1] Adepelumi A, Ako BD \& Ajayi T (2001) Ground water contamination in the basement complex area of Ile-Ife, Southwestern Nigeria. A case study using the electrical-resistivity geophysical method. Hydrogeology Journal 9, 6-11.

[2] BS 1377 (1990) Method of test for soil for Civil Engineering purposes. British Standard Institution, London.

[3] DeGroot DJ, Ostendorf DW \& Judge AI (2012) In situ Measurement of Hydraulic Conductivity of Saturated Soils. Geotechnical Engineering Journal of the SEAGS \& AGSSEA 43(4), 61-72.

[4] DIPRO (2012) DIPRO ${ }^{\mathrm{TM}}$ version 4.01.Processing and interpretation software for electrical resistivity data. KIGAM, Daejeon, South Korea.

[5] Das BM (1990) Principles of Geotechnical Engineering, Second Edition, PIOS-KENT Publishing co., Boston.

[6] Edoga RN (2010) Comparison of Saturated Hydraulic Conductivity Measurement Methods for Samaru-Nigeria Soils. Libyan Agriculture Research Center Journal International 1 (4), 269-273.

[7] Justine O (2007) Evaluation of Empirical Formulae for determination of Hyraulic Conductivity based on Grain-size analysis. Journal of Amerian Science 3(3).

[8] Katsube TJ \& Hume JP (1987) Permeability determination in crystalline rocks by standard geophysical logs. Geophysics52, 342-352. http://dx.doi.org/10.1190/1.1442308.

[9] Kodesová R, Gribb MM \& Simunek J (1998) A new CPT method for estimating soil hydraulic properties. Geotechnical Site Characterization, Robertson \& Mayne eds., A. A. Balkema, 421-1425

[10]Kodesová R, Ordway SE, Gribb MM \& Simunek J (1999) Estimating soil hydraulic properties with the cone permeameter. Field studies, Soil Science 164, 527-541. http://dx.doi.org/10.1097/00010694199908000-00001.

[11]Matsui T, Kamiide S \& Park S (1977) an applicability of resistivitybased high density prospecting to ground survey of mountain tunnel.Tsuchi-to-kiso45, 20-22.

[12]Nishimaki H, Sekine I, Saito A \& Yoshinaka R (1999) Electrical resistivity of a rock and its correlation to engineering properties. Butsuri-tansa 52, 161-171.

[13]Odong J (2013) Evaluation of Empirical Formulae for Determination of Hydraulic Conductivity based on Grain-Size Analysis. International Journal of Agriculture and Environment 1, 1-8.

[14] Ogata N, Ohsawa H, Nakano K, Yanagizawa K \& Nishigaki M (1992) Relationship among lithology, permeability and resistivity and their application to modelling of hydrogeology. J. Japan Soc. Eng. Geology32, 51-61. http://dx.doi.org/10.5110/jjseg.32.321.
[15]Olorunfemi MO \& Okhue ET (1991) Electrical resistivity investigation of a typical basement complex area- the Obafemi Awolowo University Campus case study. Journal of Mining Geology 27(2), 63-69.

[16]Pirttijärvi M (2013) DCINV, 1-D interpretation of electrical (DC) soundings, Version 1.5. Geosciences Department, University of Finland, Finland.

[17] Rahaman MA (1988) Recent advances in the study of basement complex of Nigeria. In :Oluyide PO (Ed), Precambian geology of Nigeria, Geological survey of Nigeria, pp 11-43

[18]Shevnin V, Delgado-Rodríguez O, Mousatov A \& Ryjov A (2006) Estimation of hydraulic conductivity on clay content in soil determined from resistivity data. Geofísica Internacional 45(3), 195-207.

[19]Simunek J \& van Genuchten M Th (1996) estimating unsaturated soil hydraulic properties from tension disk infiltrometer data by numerical inversion, Water Resour. Res. 32(9) 2683-2696. http://dx.doi.org/10.1029/96WR01525.

[20] Sudo H, Tanaka T, Kobayashi T, Kondo T, Miyamoto M \& Amagai M (2004) Permeability imaging in granitic rocks based on surface resistivity profiling: Exploration Geophysics 35, 56-61. http://dx.doi.org/10.1071/EG04056.

[21] Suzuki K (2002) Imaging techniques of geophysical properties for engineering by geophysical exploration. J. Japan Soc. Eng. Geology42 (6), 342-349. http://dx.doi.org/10.5110/jiseg.42.342.

[22]Xu YF \& Dong P (2004) Fractals approach to hydraulic properties in unsaturated porous media. Chaos, Solitons and fractals 19, 327-337. http://dx.doi.org/10.1016/S0960-0779(03)00045-6.

[23] Vladimir S, Omar D, Aleksandr M \& Albert R (2006) Estimation of hyraulic conductivity on clay content in soil determined from resistivity data. Geophysical International 45(3), 195-207.

[24] Vukovick M \& Soro A (1992) Determination of Hydraulic Conductivity of Porous Media from Grain-Size Composition. Water Resources Publications, Littleton, Colorado 16, 367-386.

[25] Yu L, Rogiers B, Gedeon M, Marivoet J, De Craen M \& Mallants D (2013) A critical review of laboratory and in-situ hydraulic conductivity measurements for the Boom Clay in Belgium. Applied Clay, Science, 75-76, 1-12. http://dx.doi.org/10.1016/j.clay.2013.02.018. 